\author{
Ewa Malchrowicz-Mośko \\ https://orcid.org/0000-0002-7676-1477 \\ Poznan University of Physical Education \\ Faculty of Sport Sciences \\ Department of Sport Tourism \\ malchrowicz@awf.poznan.pl \\ Joanna Poczta \\ https:/ / orcid.org/0000-0001-8825-5953 \\ Poznan University of Physical Education \\ Faculty of Sport Sciences \\ Department of Sport Tourism \\ jpoczta@awf.poznan.pl
}

\title{
MOTIVATIONS FOR RUNNING IN MEN: A COMPARATIVE ANALYSIS OF LOCAL RUNNERS AND SPORTS TOURISTS
}

\begin{abstract}
The aim of the study is to to examine the motivations for participating in a half-marathon among two groups of runners, local running in their place of residence and sports tourists, and to evaluate the differences between them. With the increase in the popularity of 'running tourism' the question becomes important as it encourages runners to engage in physical activity outside their everyday place of residence. Freyer and Gross's (2002) four types of motivation for participation in sports events was the basis for the development of the author's questionnaire. The empirical research (sample size $=346)$ then recognized these motives for participation. The article also presents a review of the literature on such motivations in mass running events. Results indicate that both group of respondents, residents of the place where the half-marathon was organised and sports tourists, have different forms of motivation. The greatest relevance for sports tourists turned out to be motivation for sensation-seeking but for local runners it was the result, and this confirms that sports tourists travel generally in search for strong emotions and sensations.
\end{abstract}

Keywords: motives for running, mass sporting event, sports tourism.

\section{INTRODUCTION}

Sports tourism is an important part of the travel industry drawing thousands of travelers and fans to various competitions and championships. In the last 30 years (since the great successes of the Olympic Games in Los Angeles and Barcelona) many cities, regions, and countries have implemented strategies to systematically organize great sports occasions, and have allocated human and financial resources to attract elite mega-sports events. Countries compete to organize the largest and most expensive global events. As a result of the difficulty of this competition, many cities and regions are turning to smaller events in the field of non-elite sports like running (not requiring an expensive infrastructure). For several years there has been discussion that small- and medium-scale sports events (such as marathons and half-marathons) can successfully contribute to the sustainable economic development of tourist destinations (Chappelet, 2015; Gibson, Kaplanidou, Kang, 2012; Taks, 2013; Taks, Green,
Misener, Chalip, 2014). Running events are sports tourism attractions that take place in many cities around the globe while marathons and half-marathons in Europe are now very popular attractions for tourists (Papanikos, 2015). Many running enthusiasts have the opportunity to travel to incredible places and run through picturesque locations full of interesting attractions such as the Athens Marathon, marathons in Lisbon, Goteborg and Oslo, the Warsaw Marathon, the International Marathon of Peace in Kosice, the Swiss City Marathon in Lucerne, the Volkswagen Marathon in Prague, the Crete Half-Marathon, half-marathons in Geneva, Bucharest, Copenhagen and Poznań, the Wizz Air Half-Marathon in Budapest and the BMW Berlin Marathon. It is important to study the socio-demographic profile of the participants of running events, their motivations and the factors which influence the popularity of running tourism and nonelite sports. 
One of these factors is the development of the ideology of healthism in western societies. Healthism, as one of the highest values of developed societies, involves the application of numerous ideas and practices that are aimed at strengthening or improving the health of the individual and encouraging others to do so. One such practice is the dissemination of physical activity. For those who adopt this ideology, (good) health is not only a means that enables continued life, but a goal in itself (Crawford, 1977, 1980). Such an understanding of health, influences changes in the role of medicine which not only cures, but also takes a preventive approach through education and testing. Crawford used it for the first time in 1980 to describe an ideology which was an important aspect of the new health awareness of American Society in the 1970s. The researcher believes that healthism is a lifestyle designed for health and fitness, and based on an individual pursuit and building motivation for the achievement of the health goals assumed (Crawford, 1994, 2004, 2006). Healthism also refers to the way in which social and moral values related to health are approached, while this process is closely related to the practices of everyday life, how people perceive themselves and their health within the social environment. That awareness has shaped American culture alongside the growth of the popularity of sports reflected by efforts to look after individual health, numerous health-promoting campaigns and the provision of health-related information in the media such as the advertisement of health products.

\section{THE DEVELOPMENT OF MASS SPORTS AND SPORTS TOURISM IN POLAND}

In the last few years, the ideology of healthism has been developing in Poland too, a trend particularly visible in the mass running events in which Poles eagerly participate. The scale of this social phenomenon is unusual on many levels and a number of interdisciplinary factors should be taken into account. The physical activity of Poles has increased dynamically in the last two decades with positive changes beginning to be observed after the political changes in 1989. Previously Polish society, unlike western countries, displayed a much lower level of physical activity. After Poland's accession to the European Union, it was at the bottom of the list of European countries in terms of physical activity; currently it is in the middle. This is rapid growth, and now the media and politicians are trying to consolidate this trend to encourage the elderly also to participate (Biernat, Piątkowska, 2012; Report on the 'Physical activity of Poles TNS Poland', 2015).

Social, cultural and economic factors have influenced this increase of physical activity. Currently, Poles are better educated, wealthier, have more free time and their quality of life has increased. They have moved to cities in which sports infrastructure has developed dynamically e.g. swimming pools, fitness clubs and bicycle paths. They also started to work more in offices. Previously, during communism, many hours were devoted to physical labour or agricultural work so running or swimming were not thought about. The end of the 1990s in Poland was a time of intense and rapid transformation of a planned economy into a free-market capitalist one. The distance between western countries and Poland was then clearly visible on many lifestyle indicators, including not only sports and recreation, and health care but also, for example, diet. Polish society started to adapt western lifestyles and a more positive perception of sports was found. In the $21^{\text {st }}$ century, Poles perceive sport as an important element of culture and social life. This increase in interest can also be explained by the organization of a sports mega-event: the European Football Championships in 2012 in Poland and Ukraine. In addition, how free time is spent allows social status to be emphasized. Sport and sports tourism have become a distinctive feature of the middle class and the fashion for running has become very visible, and not only at the place of residence (Domański, 2000; Lenartowicz, Dziubiński, Jankowski, 2017; Stempień, 2015, 2016).

Poles are still more similar, however, to the less active sporting inhabitants of southern European countries like Greece than, for example, to Scandinavia, in which the vast majority of residents are active (Biernat, Piątkowska, 2012). The favourite discipline is running (33\% of physically active people), swimming (29\%) and cycling (53\%) (Report on the 'Physical activity of Poles TNS Poland', 2015). On the other hand, the fashion for a healthy and active lifestyle has arrived, for example running events are organized even in smaller Polish towns. People want to look good and be attractive. Among physically active Poles, the mode of consumption and the forms of physical activity chosen are changing, in this respect they are heading towards western patterns. Mass sports and participation in mass sports events are developing dynamically. Increasingly, Poles are becoming sports tourists and participation in organized mass sports and recreation events has become a very attractive form of physical recreation. This can be seen primarily through the example of such events in which the turnout in recent years has increased by several hundred percentage points: Poznań Half-Marathon (increase since 2008 of 800\%), Poznań Triathlon (increase from 2013 by 300\%), Poznań Bike Challenge (increase from 2014 by 40\%), Poznań Marathon (increase from 2000 by $900 \%$ ) (own research based on data from event organizers, September 2018). In Poland, running and participation in mass events such as marathons and half-marathons has become very popular. The number of events organised and the competitors taking part in them has grown noticeably since 2000 and more than 15 large-scale marathons are held in Poland each year. These are only those events in which the 
participants are counted in thousands. Poznan is an example of a city with a population of over 500,000 with a very wide offer of sports events. More than 500 at various levels are organized annually both in the city and the Wielkopolska region, which puts Poznań among the leaders of running events nationally. This tendency raises the question of the motives behind marathon runners, particularly due to the fact that in the context of everyday life both training for and running a marathon is a kind of a luxury. It requires time and good health. Training is exhausting, and those involved in the sport go far beyond the level of physical fitness which, according to the $\mathrm{WHO}$, a healthy person should reach.

\section{MOTIVATION FOR RUNNING AS SPORTS TOURISM: A LITERATURE REVIEW}

Although there are many studies on motivations among runners (including Ogles, Masters, 2003; Ogles, Masters, Richardson, 1995) there is little research on the differences between local runners and sports tourists. Ogles, Masters \& Richardson (1995) has shown that men run for reasons such as a willingness to participate in competition, achieve success, and win against an opponent or themselves. It is also important for them to maintain health and physical fitness.

Learning about the motivation of runners and sports tourists is very important from an economic and marketing point of view. Aicher, Karadakis \& Eddosary (2015) indicated no differences in motivation between sports tourists and residents, but it was an online questionnaire. This author claims that it is better to measure opinions, sensations and the level of emotions and satisfaction during a sporting event.

According to Schwark, sports tourism may provide more opportunities for a higher intensity of experiences at the sensual-vital, emotional and social levels (Schwark, 2006). This higher intensity may be influenced by finding yourself in unusual scenery and establishing cultural and social interactions with the inhabitants of the areas visited. Doing sports outside the place of residence can therefore create a new quality not found in familiar conditions providing a higher intensity of experience (Kazimierczak, Malchrowicz-Mośko, 2013). Sports tourism creates an added value expressing the synergistic effect which internalises the autotelic values of both. A sports tourist develops not only his body but also spiritually thanks to his relationship with new natural, cultural and social environments (Szczechowicz, 2015). All this can have an impact on motivation for taking a sports trip. Therefore, it is worth investigating whether running motives are the same among local runners and sports tourists. Perhaps a sports trip provides tourists, for example, with more opportunities to satisfy emotional experiences or other needs, and this affects their motivation. Based on a review of the literature (Kazimierczak, Malchrowicz-Mośko, 2013; Schwark, 2006; Szczechowicz, 2015), the hypothesis that tourists were more satisfied with participation in a halfmarathon than residents, was accepted.

According to Zuckerman, the importance of experiencing strong emotions associated with participation in a sports event was described as sensation-seeking. To the researcher, experiencing strong emotions related to the mood of a given event, was considered one of the most important factors influencing the choice and effectiveness of various forms of sport and recreation activity (Zuckerman, 1994). People taking up sport and recreational activities more frequently feel the need to increase the effort put in and effectiveness, to participate in situations giving an opportunity to verify their own accomplishments, constantly checking and achieving a high level of stimulation. Such a phenomenon, which is defined as the search for sensation-seeking can nowadays be one of the most important factors influencing the choice and effectiveness of various forms of sport and recreational activity. According to changes towards excitement in contemporary sport and in tourism and recreation, participants are increasingly looking for extreme situations related to self-improvement, competition and, above all, experiencing intentionally controlled risk (Walczak, Tomczak, 2011; Zuckerman, 1994). Sports tourism can be seen as a product of the experience economy as contemporary tourists seek strong emotions during their travel. Nowadays, it is not enough to engage in sport and recreation activities only to enjoy their free time, but rather it is based on increasing the effort put in and the effectiveness of those activities. It is more attractive to participate in situations which provide an opportunity to verify one's own achievements, to constantly challenge oneself, and to achieve a high level of stimulation during leisure time. Today, this may be one of the most important factors influencing the choice and effectiveness of various forms of sport and recreation activity. This could explain the growing popularity of leisure activities such as marathon running. Such people are looking for forms of recreation that provide impressions and emotions connected with risk, preferring to struggle against the forces of nature, an opponent, themselves or their own weaknesses.

Many researchers are interested in the issue of human motivation and Self Determination Theory (SDT), one of the most important approaches, results from over 40 years of research. Its assumptions constitute a threepronged core that is the foundation of human development, and consists of the psychological needs for autonomy, competence, and relationships (Deci, Ryan, 2000a, 2000b; Ryan, 1995; Ryan, Deci, 2000). The need for autonomy reflects the desire for human self-determination and the choices which a person experiences when he perceives his functioning is a result of his own decisions (Ryan, La Guardia, 2000). The need for competence 
refers to the tendency for effective interactions in situations that give experience and allow for presenting skills and capabilities. In turn, the need for relationships can be satisfied with those close or with a sense of belonging to a particular social context (Ryan, La Guardia, 2000). Deci \& Ryan (2000b) mention the individual level of psychological needs and their non-hierarchical nature, emphasizing their importance for a sense of a high quality of life based on psychological development. The environment that provides stimuli to meet the needs discussed enables self-determination in an activity, the satisfaction derived from it, and internal motives for the activity which lead to a sense of pleasure and identification that is beyond the necessary (Vlachopoulos, Michailidou, 2006). Motivation is at the heart of many of sports most interesting issues, both as a developmental outcome of a social environment such as a competition or a coach's behavior, and as a developmental influence on behavioral variables such as persistence, learning and performance (Vallerand, Deci, Ryan, 1987). One perspective that has been found to be useful in this area suggests that behavior can be intrinsically motivated, extrinsically motivated, or amotivated (Deci, 1975; Deci, Ryan, 1985, 1991). This theoretical approach has generated new research pertinent to the field of sport, for example, a new measure of motivation toward sport was developed by Pelletier and his co-authors based on the tenets of Deci \& Ryan's theory. They composed a scale that measures the different forms of motivation outlined in Deci \& Ryan's theory and created a Sports Motivation Scale - SMS (Briere, Vallerand, Blais, Pelletier, 1995; Vallerand, 1997) a tool that examines the diversity of motivational processes related to participation in sport. They distinguished three dimensions: Intrinsic Motivation, Extrinsic Motivation and Amotivation in which there are seven subscales, three from Intrinsic Motivation ${ }^{1}$ (IM to Know, IM to Accomplish Things, and IM to Experience Stimulation), three for Extrinsic Motivation² (Identified, Introjected, and External), and Amotivation, ${ }^{3}$ the seventh (Briere, Vallerand, Blais, Pelletier, 1995). SMS is greatly valued in the litera-ture of sports psychology, is considered to be reliable and present a high level of internal consistency (Briere, Vallerand, Blais, Pelletier, 1995). It has been widely used not only in sports psychology, but also in mass studies into the conditioning of recreational activity in Greece and France (Alexandris, Carroll, 1997; Alexandris, Tsorbatzoudis, Grouios, 2002) and has been adopted for research in many countries (De Pero et al., 2009; Doganis, 2000). Another approach is that of Curtis \& McTeer (1981) who, using the incomplete sentence method, and based on the answers given, determined that the main reasons for taking part in marathons were achieving one's own goals, influencing others and mental well-being. Summers, Sorgent, Levey \& Murray (1982) using the same method, examined three reasons for marathon participation, determining their frequency of oc- currence, grouped them into categories based on similarity of content, and found that the most frequently mentioned were achievement of self-goals, a test of selfesteem, physical fitness, and influencing others. Johnsgård (1985), using a questionnaire, surveyed the main motives for running and his respondents reported physical fitness, mood control and self-image. Clough, Sheper \& Maugha (1989) also asked marathon runners about their reasons for running, and by means of factor analysis, identified six: challenge, physical form/ health, well-being, social, status and addiction. Tools for investigating the factors motivating people to run marathons have been introduced: Gill \& Deeter (1988) used a Sports Orientation Questionnaire (SOQ) which measures achievement in sport; Crowne \& Marlowe (1960) created the Marlow-Crowne Social Desirability Scale (MCSd) which is a scale for seeking social approval; Carmack \& Martens (1979) used the Attentional Focussing Questionnaire (AFQ) which measures associative/ dissociative attention in sports; Masters \& Lambert (1989) and Masters, Ogles \& Jolton (1993) developed the questionnaire 'Motivations of Marathoners Scale (MoMS)', measuring motives for running marathons while Freyer and Gross have distinguished four main types of motivation for participation in sports events: a) social orientation, focused on the relationships to each other; b) emo-tion/ sensation-seeking orientation, most often concerning positive experiences, in the form of relaxation, for example, which is a kind of compensation for the hardships of everyday life; c) 'factual' orientation, referring to the sports events themselves and to their specificity; in this case to running; d) result orientation, triggered by the need to identify with success, and in the case of failure, by the need to show sympathy and solidarity. The classification developed by Freyer \& Gross (2002) was the basis for the development of this writer's questionnaire on motives for participation in a running event. The questionnaire was used during the $6^{\text {th }}$ Poznań Half-Marathon.

\section{MATERIAL AND METHODS}

According to Ross's research (Ross, 2001), young men with higher education who are professionally active, are the most active participants of running events in the USA. Roberts also indicates that sports tourists are most often well-off educated men. This is due to the greater participation of men in sports in general, and the need to incur high financial costs to participate in some sports events (Roberts, 2011). In Poland men form a majority of half-marathon runners, based on data received from the organizers of previous half-marathons in Poznan. The aim was to examine the motivations of those who participate in a half-marathon among two groups 
of men: local runners (residents of Poznań) and sports tourists, and to evaluate their different motivations.

Participant data was collected during the $6^{\text {th }}$ Poznań Half-Marathon (Pol. 6. Poznań Pótmaraton) which is one of the most important mass sport events in Poland, and in which both amateur and professional runners participate. The division of motives developed by Freyer and Gross (outlined above) was the basis for developing the author's questionnaire for studying motives for participation. The results amount to more than $100 \%$ because, for each group of motives, participants could tick more than one answer (maximum 3). Descriptive statistics (percentages, means and standard deviations) were calculated for all variables. For the differences between responses of residents and sports tourists, a chi-square test was used and statistical significance was set at $p \leq 0.05$. All statistical analyses were conducted using Statistica Software 10.0 (StatSoft Inc., 2011) while pilot studies had been carried out during a previous event, the $5^{\text {th }}$ Poznań Half-Marathon.

The research, a diagnostic face-to-face survey using a standardized interview technique, was conducted among N=346 male runners in $6^{\text {th }}$ Poznań Half-Marathon. These comprised 139 residents $(\mathrm{N} 1=139)$ and 207 sports tourists $(\mathrm{N} 2=207)$ who completed a questionnaire and all of whom participated in the event voluntarily. All the sports tourists came to Poznań in order to participate and lived more than $30 \mathrm{~km}$ from the city. ${ }^{4}$ The sample was selected to ensure a good representativeness for the results. A simple random sample without replacement was used and information was obtained from the organizers on the expected number of participants. In the calculations the formula for sample size for a finite population was used with the assumption that the maximum error of estimate (e) at $95 \%$ confidence level should not exceed $4 \%$.

\section{RESULTS}

\subsection{SOCIO-DEMOGRAPHIC CHARACTERISTICS OF THE RESPONDENTS: THE PROFILE OF A RUNNER}

Most respondents were aged 26-35 (40.8\%) or 19-25 (39.3\%); $13.3 \%$ were $36-50$, while only $4.6 \%$ were $51-70$. Participants represented different educational levels, the majority had higher education (46.8\%), 29.8\% had only a secondary education with another $19.4 \%$ an incomplete higher education; $4 \%$ had just a basic education. Most of the participants came from urban areas: cities above 500,000 residents (41.3\%) and from towns with 10-100,000 residents $(40,5 \%)$ but $18.2 \%$ were from rural areas. The majority of respondents are professionally active $(58.4 \%)$ or students $(30.3 \%)$ but $4.0 \%$ were retired, $3.5 \%$ were students in secondary eduaction and $3.8 \%$ unemployed.
Table 1. Social, emotion/sensation-seeking, 'factual' and result orientations of men running a half-marathon motives $(n=346)$

\begin{tabular}{|c|c|c|}
\hline \multirow[t]{2}{*}{ Groups of motives } & \multicolumn{2}{|c|}{$\begin{array}{l}\text { Men running } \\
\text { in a half- } \\
\text { marathon } \\
(n=346)\end{array}$} \\
\hline & $\mathrm{n}$ & $\%$ \\
\hline \multicolumn{3}{|l|}{$\begin{array}{c}\text { Group A } \\
\text { Motives for social orientation }\end{array}$} \\
\hline $\begin{array}{l}\text { Desire to feel unity and integration with other } \\
\text { people }\end{array}$ & 171 & 49.40 \\
\hline Desire to feel equality during the race & 67 & 19.40 \\
\hline $\begin{array}{l}\text { Prevailing fashion - participation } \\
\text { in sports events is fashionable }\end{array}$ & 32 & 9.20 \\
\hline Desire to gain recognition in the eyes of others & 70 & 20.20 \\
\hline Participation in the subculture of runners & 97 & 28,40 \\
\hline \multicolumn{3}{|c|}{$\begin{array}{c}\text { Group B } \\
\text { Motives for sensation-seeking orientation } \\
\end{array}$} \\
\hline $\begin{array}{l}\text { Desire to experience strong emotions } \\
\text { associated with participation }\end{array}$ & 223 & 64.50 \\
\hline $\begin{array}{l}\text { Desire to feel the extraordinary mood } \\
\text { of the whole event }\end{array}$ & 164 & 47.40 \\
\hline Desire to have fun & 180 & 52.00 \\
\hline $\begin{array}{l}\text { Desire to have enjoyable leisure time / } \\
\text { entertainment }\end{array}$ & 93 & 26.90 \\
\hline $\begin{array}{l}\text { Desire to express happiness, e.g. resulting } \\
\text { from winning/success }\end{array}$ & 62 & 17.90 \\
\hline Desire to get away from everyday life & 6 & 17.60 \\
\hline $\begin{array}{l}\text { The attractiveness of the city in which the } \\
\text { event takes place }\end{array}$ & 19 & 5.50 \\
\hline \multicolumn{3}{|c|}{$\begin{array}{c}\text { Group C } \\
\text { Motives for 'factual' (specific sports discipline) orientation }\end{array}$} \\
\hline Desire to develop passion & 247 & 71.40 \\
\hline $\begin{array}{l}\text { Drawn by the attractiveness of the sports part } \\
\text { of the half-marathon }\end{array}$ & 101 & 22.00 \\
\hline $\begin{array}{l}\text { Drawn to the attractiveness of the extensive } \\
\text { program of accompanying events }\end{array}$ & 37 & 10.70 \\
\hline \multicolumn{3}{|l|}{$\begin{array}{c}\text { Group D } \\
\text { Motives for the result orientation }\end{array}$} \\
\hline Desire to test myself & 254 & 73.40 \\
\hline Desire to achieve the goal & 212 & 61.30 \\
\hline Desire to participate in sports competition & 142 & 41.03 \\
\hline Desire to win & 8 & 2.30 \\
\hline High (international) rank of this sports event & 14 & 4.00 \\
\hline None mentioned in this group & 15 & 4.30 \\
\hline \multicolumn{3}{|l|}{$\begin{array}{cc}\text { Group E } \\
\text { Other motives }\end{array}$} \\
\hline Desire to maintain good physical / health $\mathrm{f}$ & 287 & \\
\hline
\end{tabular}

Source: own development based on research, $n=346$.

Table 1 presents the most often indicated motives according to four groups: social, emotional/sensationseeking, factual and result orientations for the total sample $(n=346)$. This allows the motives of a man running a halfmarathon to be recognised. The most often indicated motive from the first group (A) was a desire to feel unity and integration with other people - 171 respondents indicated this $(49.4 \%)$. In the second group (B) the most important proved to be: desire to experience strong emotions associated with participation - 223 indicated this (64.5\%), 
along with desire to have fun - 180 respondents (52\%). The third group (C) shows that for men who participate in a half-marathon the most important aspect is a desire to develop passion connected with running - 247 indicated this (71.4\%); while the results of the last group (D) shows that the most important thing is a desire to test myself indicated by 254 respondents (73.4\%) and was the most important motive among all groups (Table 1$)$. The next motive in group $\mathrm{D}$, was a desire to achieve the goal - 212 (61.2\%) of respondents. In group E: Other motives - the Desire to maintain good physical / health fitness was indicated by the largest number of respondents (287) $82.9 \%$.

\subsection{THE MOTIVATIONS TO PARTICIPATE}

IN A HALF-MARATHON AMONG TWO GROUPS OF MEN: RESIDENTS OF POZNAŃ AND SPORTS TOURISTS: RECOGNITION OF THE DIFFERENCES

Table 2 presents Group A, social orientation, and Group B, emotion/experience orientation. The most important motive both for residents and sports tourists was a desire to feel unity and integration with other people (48.9\% and 49.8\% respectively). The second ( $\mathrm{p} \leq 0.05)$ participation in the subculture of runners was more important for sports tourists than for residents (19.4\% and 33.8\% respectively).
Affiliation to a subculture is important for only one in five of local runners but maybe they do not travel. Sports tourists who took part in the event in Poznań may have a strong need to belong to a subculture and for this reason have participated in many events outside their place of residence.

In Group B, for both the most important and statistically significant response was a desire to experience strong emotions (49.6\% for residents and $74.4 \%$ for sports tourists). This shows that this motive was more important for sports tourists confirming that they travel in search of strong impressions and emotions. The next most important motive was a desire to have fun $(56.1 \%$ for residents and $49.3 \%$ for sports tourists).

Based on a review of the literature (Kazimierczak, Malchrowicz-Mośko, 2013; Schwark, 2006; Szczechowicz, 2015), empirical research shows that sports tourists are more satisfied with participation than local runners. Participants were asked to express their level of satisfaction using the Likert scale from 1 (very dissatisfied) to 10 (very satisfied). Comparisons are proportionally graded among local and visiting runners (Table 3 ).

The conducted analysis (Mann-Whitney U Test) showed the existence of statistically significant differences between the level of satisfaction of local runners and sports tourists $(Z=9.3, p=0.0000)$. Comparison of arithmetic means and medians for both shows that the lev-

Table 2. Social orientation and sensation-seeking orientation motives

\begin{tabular}{|c|c|c|c|c|c|}
\hline \multirow[t]{2}{*}{ Groups of motives } & \multicolumn{2}{|c|}{$\begin{array}{l}\text { Residents of Poznań } \\
(\mathrm{n}=139)\end{array}$} & \multicolumn{2}{|c|}{$\begin{array}{l}\text { Sports tourists } \\
(\mathrm{n}=207)\end{array}$} & \multirow{2}{*}{$p$} \\
\hline & $\mathrm{n}$ & $\%$ & $\mathrm{n}$ & $\%$ & \\
\hline \multicolumn{6}{|c|}{$\begin{array}{c}\text { Group A } \\
\text { Motives for social orientation }\end{array}$} \\
\hline Desire to feel unity and integration with other people & 68 & 48.9 & 103 & 49.8 & 0.8786 \\
\hline Desire to feel equality during the race & 26 & 18.7 & 41 & 19.8 & 0.7993 \\
\hline Prevailing fashion - participation in sports events is fashionable & 12 & 8.6 & 20 & 9.7 & 0.7461 \\
\hline Desire to gain recognition in the eyes of others & 25 & 18.0 & 45 & 21.7 & 0.3942 \\
\hline Participation in the subculture of runners & 27 & 19.4 & 70 & 33.8 & 0.0035 \\
\hline \multicolumn{6}{|c|}{$\begin{array}{c}\text { Group B } \\
\text { Motives for sensation-seeking orientation }\end{array}$} \\
\hline Desire to experience strong emotions associated with participation & 69 & 49.6 & 154 & 74.4 & 0.0000 \\
\hline Desire to feel the extraordinary mood of the whole event & 64 & 46.0 & 100 & 48,3 & 0.6790 \\
\hline Desire to have fun & 78 & 56.1 & 102 & 49.3 & 0.2119 \\
\hline Desire to have enjoyable leisure time / entertainment & 39 & 28.1 & 54 & 26.1 & 0.6852 \\
\hline Desire to express happiness, e.g. resulting from winning/success & 32 & 23.0 & 30 & 14.5 & 0.0426 \\
\hline Desire to get away from everyday life & 21 & 15.1 & 40 & 19.3 & 0.3131 \\
\hline The attractiveness of the city in which the event takes place & 3 & 2.2 & 16 & 7.7 & 0.0257 \\
\hline
\end{tabular}

Source: own development based on research, $n=346$.

Table 3. Satisfaction in the event: local and visiting runners

\begin{tabular}{|c|c|c|c|c|c|c|c|}
\hline \multicolumn{3}{|c|}{ Local runners $\mathrm{n}=139$} & \multicolumn{3}{c|}{ Sports tourists $\mathrm{n}=207$} & \multirow{2}{*}{$\mathrm{Z}$} & \\
\cline { 1 - 6 } Average & Median & Standard deviation & Average & Median & Standard deviation & & \\
\hline 8.0 & 8.0 & 1.4 & 9.0 & 9.0 & 1.2 & 9.3 & 0.0000 \\
\hline
\end{tabular}

Source: own development based on research, $n=346$. 
el of satisfaction of visitors was higher than that of local runners. Among local runners, the mean and median were 8 , for sports tourists, they were one point higher.

In addition, sports tourists were asked whether in their opinion sports activity taken away from home provides them with stronger and more positive emotions. The results showed this for $86 \%$ of sports tourists. This may suggest that sports tourism provides more opportunities for intensity of emotional experiences than familiar settings. Respondents who answered yes to this question $(\mathrm{N}=179)$ were also asked about the extent to which activity outside their place of residence intensified emotions. The response scale was 10 - very high, 1 - very low and the average was 9.0. It should be added that this was not according to a desire to achieve the goal as local runners more often responded positively $(74.3 \%)$ compared to sports tourists $(64 \%)$.

Table 4 presents 'factual' orientation (referring to the sports events themselves and their specificity) (Group C), for result orientation (Group D) and for other motives (Group E). The most frequently indicated response in Group C, was a desire to develop passion connected with running - for residents of Poznan $(71.9 \%)$ and for sports tourists $(71.0 \%)$. In this group no statistically-significant differences were found. The most important motive from Group D for both was a desire to test myself (for residents $-77.7 \%$, for sports tourists $-70.5 \%$ ) followed by a desire to achieve the goal (58.3\% residents, $63.3 \%$ sports tourists) and a desire to participate in sports competition (41.0\% for residents, $41.1 \%$ for sports tourists). A statistically significant difference was found in group $\mathrm{D}$ for the high (international) rank of this sports event $(\mathrm{p}<0.05)$. The desire to win was not so important.
In the last group of motives (Group E), the most important was a desire to maintain good physical/health fitness for residents (82.0\%) and for sports tourists (83.6\%). No significant difference between responses was found.

The respondents were asked which motivational group was the most important for them. Figure 1 presents the motivational group percentages for respondents. Group B turned out to be the most significant for sports tourists: sensation-seeking motives (39.6\%), which confirms that sports tourists travel in search of strong sensations and emotions; for local residents it was: result motives $(40.3 \%)$ - group D, as the importance of taking part in competition or checking yourself. The desire to maintain good physical/health fitness was not the most important for runners.

Figure 1. The most important motivational group for respondents

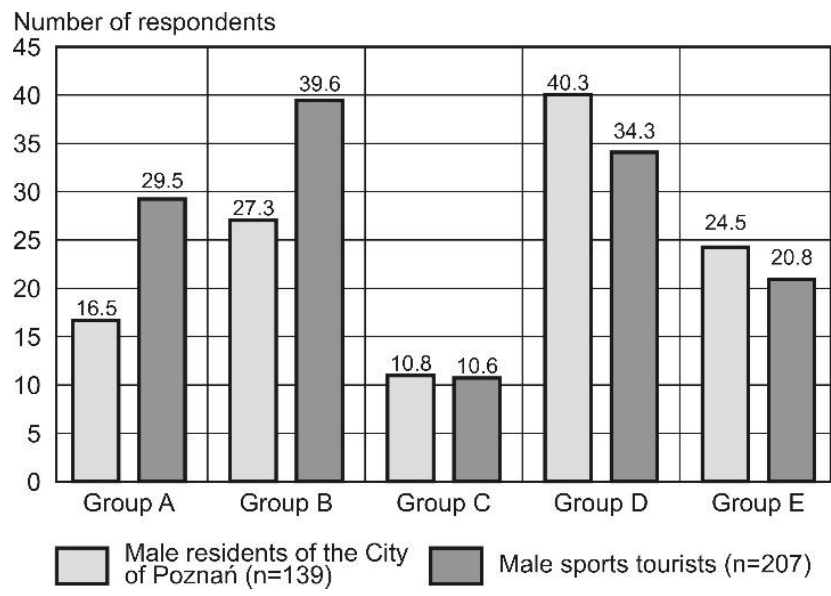

Source: own development based on research, $n=346$

Table 4. 'Factual' orientation (referring to the sports events themselves and to their specificity), for result orientation and other motives

\begin{tabular}{|c|c|c|c|c|c|}
\hline \multirow[t]{2}{*}{ Groups of motives } & \multicolumn{2}{|c|}{$\begin{array}{l}\text { Residents of Poznań } \\
(\mathrm{n}=139)\end{array}$} & \multicolumn{2}{|c|}{$\begin{array}{l}\text { Sports tourists } \\
(\mathrm{n}=207)\end{array}$} & \multirow[t]{2}{*}{$p$} \\
\hline & $\mathrm{n}$ & $\%$ & $\mathrm{~N}$ & $\%$ & \\
\hline \multicolumn{6}{|c|}{$\begin{array}{c}\text { Group C } \\
\text { Motives for 'factual' (specific sports discipline) orientation }\end{array}$} \\
\hline Desire to develop passion & 100 & 71.9 & 147 & 71.0 & 0.8515 \\
\hline I'm drawn by the attractiveness of the sports part of the half-marathon & 38 & 27.3 & 63 & 30.4 & 0.5345 \\
\hline $\begin{array}{l}\text { I'm drawn to the attractiveness of the extensive program } \\
\text { of accompanying events }\end{array}$ & 13 & 9.4 & 24 & 11.6 & 0.5083 \\
\hline \multicolumn{6}{|c|}{$\begin{array}{c}\text { Group D } \\
\text { Motives for the result orientation }\end{array}$} \\
\hline Desire to test myself & 108 & 77.7 & 146 & 70.5 & 0.1391 \\
\hline Desire to achieve the goal & 81 & 58.3 & 131 & 63.3 & 0.3482 \\
\hline Desire to participate in sports competition & 57 & 41.0 & 85 & 41.1 & 0.9918 \\
\hline Desire to win & 1 & 7.0 & 7 & 3.4 & 0.1062 \\
\hline High (international) rank of this sports event & 1 & 7.0 & 13 & 6.3 & 0.0101 \\
\hline \multicolumn{6}{|l|}{$\begin{array}{l}\text { Group E } \\
\text { Other motives }\end{array}$} \\
\hline Desire to maintain good physical / health fitness & 114 & 82.0 & 173 & 83.6 & 0.7052 \\
\hline
\end{tabular}

Source: own development based on research, $n=346$. 
The least important motivational group for both residents and sports tourists was Group C - specific sports discipline motives $(10.8 \%$ for the residents and $10.6 \%$ for sports tourists). However, the results of the research have shown something surprising - the fact that all other motives are more important than the run itself and its organization. After all, the event is primarily for running but this is not only connected with a passion for it and with health and physical fitness. This result constitutes a conceptualisation of the sporting event tourism in terms of social and psychological interactions which reveal and demonstrate its creative layers and contemporary meaning which has already gone deeply beyond functions of only meeting a need of running or care for health and physical fitness.

\section{DISCUSSION AND FINAL CONCLUSIONS}

The profile of a man running in half-marathons shows that he is young and well-educated, aged 19-35, with higher education. Most of the participants came from urban areas and they are professionally active. The profile turned out to be in accordance with the findings of Ross (2001). Ogles, Masters, Richardson (1995) showed that men usually run for reasons such as their willingness to participate in rivalry, achieve success, win against an opponent or themselves. The results of this study are similar. The most frequently reported motive was the desire to care for health and physical fitness $(82.9 \%)$ and to check myself (73.4\%). The result orientation was the most important group of motives (D) for local runners $40.3 \%$. But other motives were graded highly as well.

The most often indicated motive for all the runners from Group A was a desire to feel unity and integration with other people, in Group B the most important proved to be: desire to experience strong emotions associated with participation. Group C shows that for men who participate in a half-marathon competition the most important is to desire to develop passion connected with running. The results of Group D show that the most important is a desire to test themselves and it was the most important motive among all groups. The next motive in group $\mathrm{D}$ was a desire to achieve the goal. In group E: desire to maintain good physical / health fitness was indicated by the largest number of respondents (287). However, the motive to win against others was not that important like the motive to fight against one's weaknesses.

To evaluate the different motivations that lead to participation in a half-marathon, between residents and sports tourists, research shows that the most important from Group A, both for residents and sports tourists, was a desire to feel unity and integration with other people.
While the second statistically significant $(\mathrm{p} \leq 0.05)$ participation in the subculture of runners was more important for sports tourists than for residents.

In Group B, for all respondents, the most important and statistically-significant response was a desire to experience strong emotions, followed by a desire to have fun. This shows that the motive of strong emotions was more important for sports tourists which confirms that sports tourists travel in search of strong impressions and emotions.

These results clearly show that sports lovers travel to mass running events in search of strong emotions and build social relationships. The popularity of sports tourism, in this case marathon tourism, can be explained by the fact that it is a manifestation of a society that is focused on experiencing strong emotions (Schulze, 1992), including during travel. In addition, mass sports events have become a postmodern form of participation in social life, allowing a feeling of being part of a community of runners. The need for affiliation is now very important in western societies which currently do not create opportunities for collective behavior, unlike eastern societies. In the face of the weakening of traditional social environments in western cultures and the progressive individualization of society, the individual, not wanting to be self-reliant, actively seeks new social structures. People are looking for contact with others who lead a similar lifestyle with similar interests and views. Their physical presence, the ability to visually and tangibly realise their existence, at the same time makes sure that an individually chosen lifestyle works. Social occasions for such meetings are created by sports events.

Taking part in a sporting event usually involves a strong sense of community with other participants, it allows emotions to be shared with those around. In the postmodern world, of an atomized society, full of loneliness and loss, and full of problems with establishing and maintaining interpersonal relationships, sports events create opportunities for building social relationships and social identity. Zduniak (2010) supposes, however, that events are usually short-lived, fleeting. They offer lonely individuals an immediate sense of closeness with others, but after the end of the event the community exists no longer. Therefore, there is a need to participate in subsequent events, which may be one of the factors of the development of sports event tourism. Another important aspect is the fact that practically everyone can participate in such events as they do not put too many demands on the participants. Therefore, the human need for affiliation is satisfied virtually effortlessly, you do not have to strive for these relations. The only question is, to what extent do the events really create this desired community, and to what extent are they just meetings of lonely individuals. Perhaps they are, however, only a postmodern ritual of collective loneliness (Cudowska, 2010; Zduniak, 2010). 
The most often indicated response in Group C was a desire to develop passion, for both residents and for sports tourists but without any statistical significance between groups.

The most important from Group D for all respondents (residents and sports tourists) was a desire to test myself, a desire to achieve the goal and a desire to participate in sports competition. A statistically-significant difference between these two groups of respondents was found in response to the high (international) rank of this sports event $(p<0.05)$. In Group E, the most important was a desire to maintain good physical/health fitness for both residents and sports tourists. No significant differences were found.

The most significant for the sports tourists turned out to be group B: sensation-seeking motives, which confirms that sports tourists travel in search for strong impressions and emotions. For residents group D it was: result motives, the importance of taking part in competition or checking myself. The least important for both residents and sports tourists was Group C - specific sports discipline motives.

This result shows that while local runners focus on sports-related themes such as rivalry, sports tourism provides tourist-runners with strong impressions and emotions, and this need encourages them to travel.

The article provides data which may be useful for supporting marketing in events like half-marathons. The results give information to the organizers about the profile of runners, the needs of local runners and whether sports tourists can be attracted. High importance has been assigned, for example, to building social relations. Perhaps the program of the event should be extended to other attractions so that runners can spend more time together.

From the academic point of view, the results show the difference between a local runner and the sports tourist. The research finds an answer to the question why people go on a trip to participate in a sporting event. While for sports tourists the most important were sensationseeking motives, especially the desire to experience the strong emotions associated with participation, for residents they were result motives. According to this, sportstourism provides more opportunities to gain emotional experiences than familiar spaces. Residents are focused on the result more than tourists. Definitely, these results can provide some guidelines for sports managers to set and arrange future running events.

These results confirm the theory of Zuckerman (1994), in which he emphasizes the importance of experiencing strong emotions associated with participation in a sports event, describing them as sensation-seeking. To the researcher, experiencing strong emotions related to the mood of a given event, was considered one of the most important factors influencing the choice and effectiveness of various forms of sport and recreation. Especially for sports tourists, the strong sensations and emotions provided by sporting event participation are important.
They are seeking opportunities to establish social relations as well. In this place, the search for strong emotions and experiences may be highlighted (as we live in an experience-centered society, see Schulze's theory) which are brought to us through sporting rivalry and the possibility of making social relationships (the need to feel unity during such events) in a period of time where we live in a society of individuals. These aspects were not only a willingness to stay fit, healthy and slim, but also to build social relationships and to look for experiences and emotions that come with recreational sports, the level of satisfaction or of psychological needs to test physical fitness. Some motives like social relations have similar meaning for all runners, but other aspects such as strong emotions encourage people to travel and practice sports outside their place of residence. The research also shows that for sports tourists social relations were more important than physical activity. The popularization of running and participating in running events have a direct impact on the development of sports tourism because travelling to different places to take part in a marathon or half-marathon, gives more opportunities to gain emotional experiences and the possibility of making social relations than sport in familiar spaces.

The research results show that the dynamic growth of sports tourism is a result of different factors. It turns out that prestige and affiliation to runners' subculture is important for sports tourists and they travel primarily in search of excitement and emotions, while residents run in a half-marathon because they want to check their level of physical activity and themselves. This is more important for residents than strong emotions connected with participation in a mass event and establishing social relations.

The article constitutes a conceptualisation of the sporting event tourism in the dimension of social and psychological interactions which reveal and demonstrate its creative layers and contemporary meaning which has already gone deeply beyond functions of only meeting a need of running or care for health and physical condition. While local runners focus on sports-related themes, such as rivalry, sports tourism provides touristrunners with strong impressions and emotions, and this need encourages them to travel. Moreover, sports tourism provides more opportunities for intense experiences at an emotional level than sport in familiar settings.

The strength of the research is the sample investigated, while a limitation is the self-reporting nature of the surveys. Definitely, these results can provide some guidelines for sports managers who will set and arrange future running events. But most importantly, to understand the motives among men who participate in non-elite sports. It is also important to know the motivations among women, the young and the elderly. In the future the country of origin which may influence motivation among 
runners could be evaluated - it would be interesting to conduct similar surveys in other countries and to make a comparative analysis of motivation against a background of socio-cultural trends characteristic for a given region.

\section{ENDNOTES}

\begin{abstract}
${ }^{1}$ Intrinsic Motivation explains the behaviour of athletes who go to practice because they find it interesting and satisfying to learn more about their sports, or athletes who practice their sports for the pleasure of constantly trying to surpass themselves are considered intrinsically motivated toward their sports. Intrinsic Motivation to Know concerns athletes who are intrinsically motivated to know when they try to discover new training techniques for the sheer pleasure they experience while learning something new. Intrinsic Motivation Toward Accomplishments - defined as engaging in an activity for the pleasure and satisfaction experienced when one attempts to accomplish or create something. Intrinsic Motivation to Experience Stimulation clarify behaviour of athletes who participate in their sports in order to live exciting experiences are intrinsically motivated to experience stimulation.

${ }^{2}$ Extrinsic Motivation - contrary to intrinsic motivation, extrinsic motivation (EM) pertains to a wide variety of behaviours that are engaged in as a means to an end and not for their own sake. Identification - concerns athletes who participate in sports because they feel their involvement contributes to a part of their growth and development as a person represent an example of identified motivation. for why they continue to train. Introjection - athletes who participate in sportss because they feel pressure to be in good shape for aesthetic reasons, and feel embarrassed or ashamed when they are not in best form. External Regulation describes athletes who participate in sports in order to receive praise from their coach or because they feel urged to do so by their parents are motivated by external regulation.

${ }^{3}$ Amotivation - motivate individuals do not perceive contingencies between their actions and the outcomes of their actions. They experience feelings of incompetence and lack of control. They are neither intrinsically motivated nor extrinsically motivated. When athletes are in such a state, they no longer identify any good reasons for why they continue to train. Eventually they may even decide to stop practicing their sports.

${ }^{4}$ We didn't check if they were domestic or foreign tourists. It should be ckecked in the future because the country of origin may influence on motivations. The designed questionnaire did not take into account any specific conditions of Poland.
\end{abstract}

\section{BIBLIOGRAPHY}

Aicher, T., Karadakis, K., Eddosary, M. (2015). Comparison of sports tourists' and locals' motivation to participate in a running event. International Journal of Event and Festival Management, 6 (3), 215-234.

Alexandris, K., Carroll, B. (1997). An analysis of leisure constraints based on different recreational sports levels: Results from a study in Greece. Leisure Science, 19 (1), 1-15.

Alexandris, K., Tsorbatzoudis, Ch., Grouios, G. (2002). Perceived constraints on recreational sports participation: Investigating their relationship with intrinsic motivation, extrinsic motivation and amotivation. Journal of Leisure Research, 2 (34), 233-252.

Biernat, E., Piątkowska, M. (2012). Recreational physical activity of Poles in the light of Europe - report. Warszawa: Ministerstwo Sportu i Turystyki.

Briere, N.M.; Vallerand, R.J.; Blais, M., Pelletier, L.G. (1995). Developpement et validation d'une mesure de motivation intrinsfeque et extrinseque et d'amotivation en contexte sportsif: L'Echelle de Motivation vis-à-vis les Sports (EMS). International Journal of Sports Psychology, 4 (26), 465-489.

Carmack, M.A., Martens, R. (1979). Measuring commitment to running: A survey of runners' attitudes and mental states. Journal of Sports Psychology, 1 (1), 25-42.

Chappelet, J.L. (2015). Heritage sportsing events and place marketing. In: M. Plevnik (ed.), Sustainable development of sports tourism. Koper: Annales University Press.

Clough, P.J., Sheper, J., Maugha, R. (1989). Motives for participation in recreational running. Journal of Leisure Research, 21 (4), 297-309.

Crawford, R. (1977). You are dangerous to your health: The ideology and politics of victim blaming. International Journal of Health Services, 7 (4), 663-680.

Crawford, R. (1980). Healthism and the medicalization of everyday life. International Journal of Health Services, 10 (3), 365-388.

Crawford, R. (1994). The boundaries of the self and the unhealthy other: Reflections on helth, culture and AIDS. Social Science and Medicine, 38 (10), 1347-1365.

Crawford, R. (2004). Risk ritual and the management of anxiety in medical culture. Health: An Interdisciplinary Journal for the Social Study of Health, Illness and Medicine, 8 (4), 505-552.

Crawford, R. (2006). Health as a meaningful social practice. Health: An Interdisciplinary Journal for the Social Study of Health, Illness and Medicine, 10 (4), 401-420.

Crowne, D.P., Marlowe, D. (1960). A new scale of social desirability independent of psychopathology. Journal of Consulting Psychology, 24 (4), 349-354.

Cudowska, A. (2010). Wspólnota w kulturze indywidualizmu. Retrieved from: https://repozytorium.uwb.edu.pl/jspui/bitstream/11320/2729/1/Agata\%20Cudowska_Wsp\%c3\%b31nota\%20w\%20kulturze\%20indywidualizmu.pdf (13.08.2019).

Curtis, J., McTeer, W. (1981). The motivation for running. Canadian Runners, 1, 18-19.

De Pero, R., Amici, S., Benvenuti, C., Minganti, C., Capranica, L., Pesce, C. (2009). Motivation for sports participation in older italian athletes: The role of age, gender and competition level. Sports Science and Health, 5 (2), 61-69.

Deci, E.L. (1975). Intrinsic motivation. New York: Plenum.

Deci, E.L., Ryan, R.M. (1985). Intrinsic motivation and self-determination in human behavior. New York: Plenum Press.

Deci, E.L., Ryan, R.M. (2000). Intrinsic and extrinsic motivations: classic definitions and new directions. Contemporary Educational Psychology, 25 (1), 54-67.

Deci, E.L., Ryan, R.M. (1991). A motivational approach to self: Integration in personality. In: R. Dienstbier (ed.), Nebraska symposium on motivation: Perspectives on motivation. Vol. 38 (pp. 237-288). Lincoln, NE: University of Nebraska Press.

Deci, E.L. Ryan, R.M. (2000). The "what" and "why" of goal pursuits: Human needs and the self-determination of behavior. Psychological Inquiry, 11 (4), 227-268.

Doganis, G. (2000). Development of a Greek version of the sports motivation scale. Perceptual and Motor Skills, 90 (2), 505-512.

Domański, H. (2000). Polska klasa średnia. Wrocław: Wydawnictwo Uniwersytetu Wrocławskiego.

Freyer, W., Gross, S. (2002). Tourismus und sports-events. Dresden: FIT Forschungsinstitut für Tourismus. 
Gibson, H., Kaplanidou, K., Kang, S.J. (2012). Small-scale event sports tourism: A case study in sustainable tourism. Sports Management Review, 15 (2), 160-170.

Gill, D.L., Deeter, T.E. (1988). The development of the sports orientation questionnaire. Research Quarterly for Exercice and Sports, 59 (3), 191-202.

Johnsgård, K. (1985). The motivation of the long distance runner. Journal of Sports Medicine, 25, 135-139.

Kazimierczak, M., Malchrowicz-Mośko, E. (2013). Specific and developmental trends of sports tourism. Folia Turistica, 28, 67-90.

Lenartowicz, M., Dziubiński, Z., Jankowski, K. (2017). Aktywni Polacy: dwie dekady uczestnictwa w sporcie i rekreacji ruchowej. Próby wyjaśnienia zmian. Kultura i Społeczeństwo, 2, 117-132.

Masters, K.S., Lambert, M.J. (1989). The relation between cognitive coping strategies, reasons for running, injury, and performance of marathon runners. Journal of Sports and Exercise Psychology, 11, 161-170.

Masters, K.S., Ogles, B.M., Jolton, J.A. (1993). The development of an instrument to measure motivation for marathon running: The motivation of marathoners scales (MoMS). Research Quarterly for Exercice and Sports, 64 (2), 134-143.

Ogles, B.M., Masters, K.S. (2003). A typology of marathon runners based on cluster analysis on motivations. Journal of Sports Behaviour, 26 (1), 69-85.

Ogles, B.M., Masters, K.S., Richardson, S.A. (1995). Obligatory running and gender: An analysis of participative motives and training habits. International Journal of Sports Psychology, 26, 233-248.

Papanikos, G. (2015). The economic effects of a marathon as a sports tourism event. Athens Journal of Sports, 1 (225), 225-240.

Report "Physical activity of Poles TNS Poland" (2015). Warsaw: TNS.

Roberts, C. (2011). Sports and adventure tourism. In: P. Robinson, S. Heitmann, P. Dicke (eds), Research themes for tourism. Oxfordshire-Cambridge, UK: CABI Publisher.

Ross, D. (2001). What are the characteristics of sport tourists? In: D. Ross, Developing sports tourism. National Laboratory for Tourism. Urbana - Champaign, Illinois: University of Illinois.

Ryan, M.R. (1995). Psychological needs and the facilitation of integrative processes. Journal of Personality, 63 (3), 397-427.

Ryan, R.M. Deci, E.L. (2000). Self-determination theory and the facilitation of intrinsic motivation, social development, and wellbeing. The American Psychologist, 55 (1), 68-78.

Ryan, R.M. La Guardia, J.G. (2000). What is being optimized over development? A self-determination theory perspective on basic psychological needs across the life span. In: S. Qualls, N. Abeles (eds.), Psychology and the aging revolution (pp. 145-172). Washington: APA Books.

Schulze, G. (1992). Die Erlebniz-Gesellschaft. Kultursoziologie der Gegenwart, Frankfurt am Main: Campus-Verlag.
Schwark, J. (2006) Grundlagen zum Sportstourismus. Münster-New York-München-Berlin: Waxmann.

Stempień, J.R. (2015). Polska moda na bieganie w świetle analizy kohort. Perspektywa socjologiczna. In: M. Zowisło, J. Kosiewicz (eds.), Sports i turystyka w zwierciadle wartości społecznych (pp. 450-460). Kraków: Wydawnictwo Akademii Wychowania Fizycznego w Krakowie.

Stempień, J.R. (2016). Bieganie, zwiedzaniei klasa średnia - przygarść socjologicznych uwag i obserwacji o turystyce biegowej. In: M. Kazimierczak (ed.), Inspiracje sportem w turystyce kulturowej (39-49). Poznań: Wydawnictwo Akademii Wychowania Fizycznego w Poznaniu.

Summers, J.J., Sargent, G.I., Levey, A.J., Murray, K.D. (1982). Middle aged, non-elite marathon runners: a profile. Perceptual and Motor Skills, 54 (3), 963-969.

Szczechowicz, B. (2015). Łączenie wartości turystyki i sportu w świetle analizy ofert rynkowych. In: M. Kazimierczak (ed.), Turystyka sportowa - społeczno-kulturowy potencjat i perspektywy rozwoju (pp. 41-53). Poznań: Wydawnictwo Akademii Wychowania Fizycznego w Poznaniu.

Taks, M. (2013). Social sustainability of non-mega sports events in a global world. European Journal for Sports and Society, 10 (2), 121-141.

Taks, M., Green, Ch., Misener, L., Chalip, L. (2014). Evaluationg sports development outcomes: The case of a medium-sized international sports event. European Sports Management Quarterly, 14 (3), 213-237.

Vallerand, R.J. (1997). Toward a hierarchical model of intrinsic and extrinsic motivation. In: M.P. Zanna (ed.), Advances in experimental social psychology. Vol. 29 (pp. 271-360). San Diego, CA: Academic Press.

Vallerand, R.J., Deci, E.L., Ryan, R.M. (1987). Intrinsic motivation in sports. In: K.B. Pandolf (ed.), Exercise and sports sciences reviews. Vol. 15 (pp. 389-425). New York: MacMillan.

Vlachopoulos, S.P., Michailidou, S. (2006). Development and initial validation of a measure of autonomy, competence, and relatedness in exercise: The basic psychological needs in exercise scale. Measurement in Physical Education and Exercise Sciences, 10, 179-201.

Walczak, M. Tomczak, M. (2011). The structure of psychological determinants of selected aspects of physical activity in the light of the theory of self-determination. Sports and Recreation and the Challenge of Modern Civilization; Scientific Notebooks of Szczecin University, 689; Economic Issues Services, 78, 127-152.

Zduniak, A. (2010). Event jako ponowoczesna forma uczestnictwa w życiu społecznym. Roczniki Nauk Społecznych, 2 (38), 207-234.

Zuckerman, M. (1994) Behavioral expressions and biosocial bases of sensation seeking. New York: Cambridge Press.

Article received:

12 July 2019

Accepted:

21 October 2019 
